JURNAL ILMIAH MUQODDIMAH:

Jurnal IImu Sosial, Politikk Dan Humaniora

\title{
JAMINAN HAK PILIH BAGI NARAPIDANA PADA PEMILU 2019 DI RUMAH TAHANAN KELAS I PEKANBARU
}

\author{
Hadipurwoko ${ }^{1}$, Wawan Budi Darmawan ${ }^{2}$, Ari Ganjar Herdiansyah ${ }^{3}$ \\ Konsentrasi Tata Kelola Pemilu Program Studi Magister IImu Politik \\ Fakultas IImu Sosial Dan IImu Politik Universitas Padjadjaran ${ }^{1}$ \\ Fakultas IImu Sosial Dan IImu Politik Universitas Padjadjaran ${ }^{2}$ \\ Fakultas IImu Sosial Dan IImu Politik Universitas Padjadjaran ${ }^{3}$ \\ wokopsp@gmail.com ${ }^{1}$ \\ wawan.budi.darmawan@unpad.ac.id ${ }^{2}$ \\ Ari.Ganjar@unpad.ac.id ${ }^{3}$
}

\begin{abstract}
Abstrak
Secara teknis, jaminan hak memilih sangat dipengaruhi oleh sejauhmana seorang warga negara masuk ke dalam daftar pemilih, namun terdapat hambatan terkait hak pilih tahanan dan narapidana di rutan kelas I Pekanbaru, pada Pemilu serentak 2019,. Dari penghuni tahanan dan narapidana yang berjumlah 1688 orang, pada tanggal 17 April 2019 hanya 33 orang yang dapat dimasukan dalam data pemilih pada tempat pemungutas suara setempat, dan yang menggunakan hak pilih hanya 20 orang, sehingga hampir 98 persen warga binaan tidak dapat memilih pada saat hari pemungutan suara,. Penelitian ini adalah penelitian deskriptif kualitatif dengan menggunakan metode wawancara,dan studi kepustakaan. Metode penelitian yang digunakan adalah deskriptif kualitatif. Lokasi penelitian adalah Rumah Tahanan Kelas I Pekanbaru. Hasil penelitian ini menunjukkan penyebab tahanan dan narapidana tidak dapat menggunakan hak pilihnya, karena disebabkan oleh sulitnya menelusuri data otentik tahanan dan narapidana di rutan, karena sebagian besar data warga binaan hanya berasal dari berkas pengadilan yang hanya berupa nama, jenis kelamin. Tidak memuat nomor induk kependududkan karena indentitas tahanan dan narapidana tidak lengkap, maka jaminan hak pilih warga binaan di Rutan Kelas I Pekanbaru hanya dilaksanakan secara normatif oleh KPU Kota Pekanbaru sesuai tahapan dan prosedur yang berlaku, sehingga banyak narapidana yang berasal dari luar daerah tidak dapat diakomodir hak pilinnya. Perlu koordinasi antar lembaga yang lebih kuat dan berkesinambungan dan menambah regulasi yang dapat mempermudah proses pendataan tahanan dan narapidana ke dalam data pemilih
\end{abstract}

Kata kunci: Hak Pilih, Pemilu Inklusif, Narapidana

\begin{abstract}
Technically, the guarantee of the right to vote is strongly influenced by the extent to which a citizen is on the voter list, but there are obstacles related to the suffrage and prisoner suffrage in the Pekanbaru class I detention center, in 2019 simultaneous elections. Of the inmates and prisoners numbering 1688 people, on April 17, 2019 only 33 people could be entered in the voter data at the local polling stations, and only 20 people exercised their voting rights, so that almost 98 percent of the target population could not vote at the time polling day, This research is a qualitative descriptive study using the interview method and literature study. The research method used is descriptive qualitative. The research location is Pekanbaru Class I Detention Center. The results of this study indicate the cause of detainees and prisoners cannot exercise their voting rights, because it is caused by the difficulty in tracing authentic data of prisoners and prisoners in detention, because most of the
\end{abstract}


data of fostered citizens only comes from court files which only consist of name, gender. Does not contain the presidential identification number because the identity of detainees and prisoners is incomplete, then the guarantee of voting rights for inmates in Pekanbaru Class I Detention Center is only carried out normatively by the Pekanbaru City KPU in accordance with the applicable stages and procedures, so that many prisoners from outside the area cannot be accommodated his vote. There is a need for stronger and more sustainable interagency coordination and additional regulations that can facilitate the data collection process of prisoners and prisoners into voter data

Keywords: Voting Rights, Inclusive Elections, Prisoners

\section{PENDAHULUAN}

Jaminan hak memilih dan hak dipilih diatur di dalam konstitusi dan berbagai peraturan perundangan undangan lainnya. Pasal 6, 6A dan Pasal 7 dalam UUD 1945 juga mengatur mekanisme pencalonan dan pemilu untuk pemilihan presiden dan wakil presiden (pilpres). Selain itu, Pasal 22E UUD 1945 mengatur secara umum tentang Pemilu. Pengaturan juga terdapat pada Pasal 28D Ayat (3). Lebih lanjut, hak memilih dan hak dipilih diatur di dalam UU No. 7 Tahun 2017 tentang Pemilihan Umum dan UU No. 10 Tahun 2016 tentang Perubahan Kedua Atas Undang-Undang Nomor 1 Tahun 2015 Tentang Penetapan Peraturan Pemerintah Pengganti UndangUndang Nomor 1 Tahun 2014 Tentang Pemilihan Gubernur, Bupati, Dan Walikota Menjadi Undang-Undang.

Selain pentingnya hak politik bagi pemilu, penyelenggara pemilu juga merupakan lembaga politik yang sangat penting bagi pelaksanaan hak politik warga negara. Dalam konteks ini, kita perlu melihat kembali fungsi-fungsi pemilu. Pemilu berfungsi sebagai mekanisme untuk menterjemahkan kembali preferensi publik sehingga menghasilkan legitimasi kekuasaan yang baru. Siklus pemilu memungkinkan mekanisme ini berjalan secara berkala. Lebih jauh tentang hak memilih, terdapat tiga pendekatan dalam menentukan siapa yang berhak memilih untuk menjamin hak memilih yang luas (Beckman, 2008)

Pertama adalah pendekatan minimalis, dimana pendekatan ini menentukan kriteria yang sangat luas dalam menentukan siapa yang dapat menggunakan hak suaranya di pemilu. Kedua adalah pendekatan konvensionalisme, dimana pendekatan ini menentukan kriteria-kriteria tertentu dalam menentukan layak atau tidaknya seorang warga negara untuk menjadi pemilih.

Dengan demikian, pendekatan ini membuka ruang bagi terjadinya proses eksklusi sehingga tidak semua warga negara memiliki hak memilih. Ketiga adalah pendekatan maksimalis, dimana pendekatan ini menentukan kriteria yang sangat tinggi dalam menentukan siapa yang mempunyai hak memilih. Dibandingkan dengan kedua pendekatan sebelumnya, pendekatan ini memiliki batasan kriteria-kriteria yang sangat ketat dalam mendefinisikan seorang warga negara dapat menjadi seorang pemilih.

Berdasarkan data KPU RI pada Pilpres dan Pileg 2019, jumlah pemilih yang tidak menggunakan hak pilihnyaberjumlah 41.975.364 orang atau 19 persen dari 199.987.870 orang pemilih. . Secara teoritik, terdapat berbagai faktor yang menjelaskan mengapa pemilih tidak menggunakan hak pilinnya..salah satunya alasan administrasi, dimana pemilih tidak dapat menggunakan hak pilinnya karena adanya kendala atau hambatan administrasi(Sanit, 1992).

Permasalahan administrasi ini berpotensi besar menimpa kelompok masyarakat rentan, misalnya seperti masyarakat yang berada dalam masa penahanan atau di Lembaga 
Pemasyarakat (Lapas). Akibat keterbatasan ruang informasi dan administrasi di dalam Lapas, mereka tidak mampu mengakses proses pendaftaran pemilih, yang berakibat nama mereka akhirnya tidak masuk dalam daftar pemilih. Karena nama mereka tidak masuk dalam daftar pemilih, maka mereka tidak bisa mengunakan hak pilinnya pada hari pemungutan suara.

Permasalah terkait Daftar Pemilih, sebenarnya tidak saja terjadi di Pemilu 2019, namun juga terjadi di pemilu-pemilu dan pilkada-pilkada sebelumnya (Fadli, dkk. 2019 : 8-17). Pada Pilkada serentak tahun 2018 yang lalu permasalahan mengenai data pemilih di Lapas diungkapkan oleh Komnas HAM yang merekomendasikan KPU untuk membuat Tempat Pemungutan Suara (TPS) di Lapas serta perlu ada regulasi khusus bagi calon pemilih di Lapas dan Rumah Sakit, karena Komnas HAM menilai penguni Lapas berpotensi sulit menggunakan hak suaranya di Pilada Serentak 2018. ${ }^{1}$

Insentitas masalah kemudian terjadi juga di dalam konteks Pemilu 2019 terkait Tahanan dan Narapidana, yaitu lambatnya respon untuk masuk kedalam proses tahapan pemilu seperti pemilih tahanan dan narapidana yang memenuhi syarat sebagai pemilih yang pada saat hari pemungutan suara berada di Rumah Tahanan (Rutan) atau Lembaga pemasyarakatan (Lapas).

Sri Puguh Budi Utami, Direktur Jenderal Pemasyarakatan (Ditjen PAS) Kementerian Hukum dan HAM mengatakan pihaknya telah berupaya agar para narapidana maupun tahanan bisa menggunakan hak pilihnya dalam Pilpres 2019. Ditjen Pas, telah berkoordinasi dengan Direktorat Jenderal Kependudukan dan Pencatatan Sipil (Dukcapil) Kementerian Dalam Negeri,

\footnotetext{
${ }^{1}$ Diaksesdarihttp://infopublik.id/read/262892/komnasham-minta-ada-tps-khusus-dan-regulasi-bagi- pemilihlapas.html di akses tanggal 13 Desember 2019
}

untuk melakukan perekaman data narapidana atau tahanan yang belum memiliki e-KTP. Hingga senin, 15 April 2019 tercatat dari 262.000 narapidana dan tahanan, baru 116.000 yang masuk ke dalam DPT. Sementara, sisanya, 11.000 narapidana masuk ke dalam DPTb. Jumlah ini terangkum dari 522 lembaga pemasyarakatan dan rumah tahanan yang ada di Indonesia dan akan terus bertambah. ${ }^{2}$

Jika kita memperhatikan fakta di atas, menjelang dua hari pemungutan suara, hampir $60 \%$ pemilih di Lapas Se Indonesia belum tercatat di dalam DPT, atau dia terdaftar di DPT tempat tinggalnya, namun tidak memiliki akses informasi di TPS mana dia berhak mencoblos, sehingga tidak memenuhi syarat untuk memilih di TPS yang berada di Lapas atau Rutan. Selanjutnya dari data di atas hanya 11.000 yang telah melakukan pengurusan pindah memilih.

Permasalahan administrasi calon pemilih di Lapas dan rutan yang belum bisa terverifikasi adalah data penghuni hanya nama dan alamat, NIK dan KTP tidak diketahui, dan penghuni Lapas tidak membawa KTP el atau Surat Keterangan menjadi hambatan saat pencoblosan ${ }^{3}$. Identitas dari penghuni Lapas yang sulit untuk ditelusuri ini menjadi hambatan bagi KPU untuk menyusun Daftar Pemilih Tetap (DPT) dan Daftar Pemilih Tambahan (DPTb).

Penelusuran identitas penghuni Lapas menjadi faktor penting dalam hal memfasilitasi pemilih di dalamnya. Kepemilikan KTP elektronik yang harus dimiliki penghuni Lapas menjadi kewenangan Dinas Kependudukan dan Catatan Sipil setempat untuk segera melakukan pendataan dan perekaman.

\footnotetext{
${ }^{2}$ https://tirto.id/hanya-1110-narapidana-yang-tercatatdalam-dpt-di-lapas-cipinang-dmvK di akses tanggal 2 Desember 2019.

${ }^{3}$ https://www.liputan6.com/regional/read /3943810/tidak-semua-napi-lapas-bisa-nyoblosmengapaDi akses pada tanggal 29 November 2019
} 
Permasalahan penghuni rutan dan lapas yang sebagian penghuninya tidak memberikan identitas yang valid juga menjadi problem utama dalam pendataan dan perekaman nantinya. Jika calon pemilih tersebut telah melakukan perekaman data dalam KTP Elektronik, kemungkinan akan mudah dilakukan penelusuran, tetapi jika belum pernah dilakukan perekaman maka harus ada solusi yang harus dilakukan oleh dinas kependudukan untuk mengetahui identitas calon pemilih. Karena jika narapidana atau tahanan di Rutan atau Lapas banyak yang tidak memiliki kartu tanda penduduk atau KTP Elektronik, makamenjadi salah satu penyumbang angka golput dalam pemilu 2019.

Berdasarkan pengamatan penulis dari beberapa referensi artikel bahwa selama Pemilu Legislatif, Presiden dan Wakil Presiden serta Pilkada Serentak yang dilakukan di beberapa daerah, Pelaksanaan pemungutan suara di Rutan dan Lapas hanya dilakukan terhadap napi yang masuk dalam DPT dan DPTb, artinya hanya napi yang bedomisili di daerah Lapas setempat yang di fasilitasi hak pilih di TPS atau Napi yang mendapatkan formulir A5 sebelum pencoblosan. Seperti yang terjadi di Jawa Barat dan Sumatera Utara, dalam hal ini Pramono menyebutkan ${ }^{4}$ : bahwa data para pemilih Lapas, yakni sebanyak 20 ribu pemilih di Sumatra Utara (Sumut) dan 37 ribu penghuni Lapas di Jabar memang belum termasuk dalam data pemilih yang saat ini berstatus belum memiliki KTP-el. Sebagaimana diketahui, saat ini ada 849 ribu pemilih Pilkada 2018 yang belum memiliki KTP-el"

Untuk mendata pemilih di luar domisili pun memang harus ada kordinasi yang baik antar KPU tingkat Kabupaten/Kota bekerja bekerjasama dengan Dinas Kependudukan dan

\footnotetext{
${ }^{4}$ Suber dari : http://infopublik.id/read/262892/komnasham-minta-ada-tps-khusus-dan-regulasi- bagi-pemilihlapas.htmldi akses tanggal 10 Desember 2019
}

Catatan Sipil. Hal ini yang belum ada di regulasi, aturan dan petunjuk teknis KPU yang dapat mengurai hambatan dalam administrasi daftar pemilih.

Kasus di atas terjadi pada Rumah Tahanan (Rutan) Kelas I Pekanbaru, terdapat permasalahan yang signifikan menggambarkan kesenjangan pelaksanaan administrasi daftar pemilih sehingga menghilangkan hak pilih Tahanan dan Narapidana. Dari penghuni Tahanan dan Narapidana yang berjumlah 1688 orang, pada tanggal 17 April 2019 hanya 33 orang yang tercatat ke dalam data pemilih dan yang menggunakan hak pilih hanya 20 orang $^{5}$. Ini menandakan bahwa permsalahan regulasi dan administrasi penjaminan hak pilih bagi Tahanan dan Narapidana masih terus terjadi dan berulang.

Seharusnya seluruh tahanan dapat dipastikan bahwa mereka terdaftar dalam DPT maupun DPTb, dan juga karena tidak dapat memilih di tempat asalnya, Tahanan dan Narapidanaharusnya dapat dipastikan dapat memilih di Rutan atau Lapas tempat mereka ditahan. Namun, realitanya hampir seluruh Tahanan dan Narapidana di Rutan Kelas I Pekanbaru tidak dapatdapat memilih pada hari pencoblosan.

Penulis menilai masalah minimnya hak pilih warga binaan di Rutan Kelas I Pekanbaru ini penting untuk diteliti penyebabnya, karena hak pilih warga negara dalam wujud Pemilu Inklusif adalah salah satu gambaran demokratisnya pemilu, adanya prinsip kehati-hatian dalam penanganan administrasi daftar pemilih oleh Electoral Management Body (EMB) atau

\footnotetext{
${ }^{5}$ Data di ambil dari Formulir Model C1-PPWP TPS 60 Kel. Sialang Sakti Kec. Tenayan Raya Pekanbaru. Dan Rekap bulanan penghuni Rumah Tahanan Kelas I Pekanbaru Tahun 2019. Di akses melalui http://smslap.ditjenpas.go.id/public/grl/detail/monthl y/upt/02b46830-8a05-1a05-df37313133343439/year/2019 pada tanggal 14 Februari 2020.
} 
penyelenggara pemilu, tentu akan dapat meminimalisasi tidak terakomodirnya hak pilih Tahanan dan Narapidana.

Ditambah dengan argumen bahwa Tahanan dan Narapidana adalah warga negara yang jelas posisi dan keberadaannya selama tahapan Pemilu, karena berada di lingkungan yang tidak memungkinkan untuk berpindah dalam waktu tertentu, hanya saja diperlukan Tata Kelola Pemilu (Electoral Governance) yang baik dalam memformulasikan regulasi yang dapat mengurai permasalahan terkait adminitrasi daftar pemilih bagi Tahanan dan Narapidana. Sehingga isu jaminan hak pilih bagi Tahanan dan Narapidana ini menjadi relevan untuk dikaji guna perbaikan kualitas Pemilu yang demokratis dan berintegritas.

Secara teknis, jaminan hak memilih sangat dipengaruhi oleh sejauhmana seorang warga negara kemudian masuk di dalam daftar pemilih. Terdapat beberapa kriteria untuk berbagai upaya dalam menjamin hak memilih secara luas sebagaimana dijelaskan oleh Yard (2011 : 2-3), yaitu 1. Integritas, dimana proses pendaftaran pemilih harus adil, jujur dan benar-benar dapat menjangkau semua yang telah memenuhi syarat menjadi pemilih dan, sebaliknya, benar- benar mengeksklusi mereka yang tidak memenuhi syarat sebagai pemilih. 2 . Inklusivitas, yakni semua pemilih yang memenuhi persyaratan harus terdaftar tanpa mempertimbangkan pilihan politik, agama, suku dan yang lainnya. 3 . komprehensivitas, pendaftaran perlu lebih fokus pada mereka yang selama ini termarginalisasi, misalnya perempuan, kelompok disabel, pemuda, kelompok miskin, mereka yang tinggal di daerah terpencil, dan lainnya. 4. akurasi, dimana data pendaftaran perlu direkam dan dikelola untuk menjamin keakuratan. 5. Aksesibilitas, : tidak seorangpun mengalami kendala jarak dan hambatan fisik untuk dimasukkan di dalam daftar pemilih. 6. Transparansi, semua proses pendaftaran dan pemutakhiran data pemilih harus terbuka kepada semua pihak. 7. Keamanan: semua data harus dilindungi dari mereka yang tidak berwenang untuk mengakses data dan dilindingi dari kehilangan data akibat kesalahan atau bencana; 8. Akuntabilitas: semua perubahan pada proses pendaftaran pemilih harus sesuai dengan peraturan perundangan dan semua keputusan harus melibatkan partisipasi publik; 9. Kredibilitas: data pemilih musti dikompilasi dan dikelolal sedemikian rupa sehingga dapat menjaga kepercayaan publik dan para pengampu kepentingan, 10. Keberlangsungan: proses pendaftaran pemilih harus dilakukan sedemikan rupa sehingga dapat dikelola atau diulangi dari segi apapun;. 11. Efektivitas: pendaftaran pemilih perlu dilakukan secara memadai dari segi keuangan (murah tidak selalu berarti jelek dan mahal tidak selalu berarti baik); 12. Pemilih yang terinformasi: pemilih harus tahu kapan, di mana dan bagaimana untuk memastikan mereka terdaftar serta di mana mereka akan memilih.

Lebih lanjut Birch (2011: 17-21) memandang dalam sebuah demokrasi harus mengandung prinsip inklusif di dalamnya. Birch menjadikan inklusif sebagai salah satu dari 3 prinsip untuk mewujudkan demokrasi. dimana semua orang berhak untuk dipilih dan memilih tanpa hambatan apapun. Birch mengemukakan bahwa untuk dapat mewujudkan hal tersebut,Pemilu yang demokratis harus menjamin setidaknya tiga hal yaitu; hak pilih, kesempatan untuk memilih, dan hak untuk dipilih. Menariknya lagi, dari tiga hal tersebut Birch menjelaskan bahwa untuk terciptanya itu semua maka administrasi Pemilumenjadi kunci untuk menjamin hak pilih dan dipilih.

Menurut Ramlan Surbakti (2016), parameter kesetaraan antar warga 
Negara dalam hak pilih setidaknya dapat dilihat dari tiga indikator. Pertama,Cakupan. Yaitu jumlah warga Negara berhak memilih yang telah terdaftar dalam Daftar Pemilih Tetap (DPT). Kedua,Kemutakhiran yaitu Daftar pemilih tetap tidak lagi berisi sejumlah warga Negara yang tidak lagi memenuhi syarat sebagai pemilih., dan terakhir, Akurasi yaitu jumlah warga yang nama dan identitasnya telah ditulis sesuai dengan seharusnya

Pemilu inklusif berfokus pada cakupan daftar pemilihnya dan pada cakupan pengguna hak pilihnya yaitu tingkat partisipasi mereka dalam Pemilu. Sehingga Semakin luas cakupan daftar pemilih yang dibuat semakin inklusif daftar pemilih tersebut, Semakin tinggi pengguna hak pilih (voter's turnout) menandakan semakin banyak kategori pemilih yang dilayani. Hal ini berarti sistem Pemilu yang diterapkan telah mampu mengakomodir kebutuhan kategori pemilih yang berkebutuhan khusus. Sistem Pemilu yang ada telah mampu menghilangkan hambatan di dalam mewujudkan universal suffrage, perwujudan kesetaraan warga Negara sesuai dengan parameter Pemilu yang demokratis

Rujukan dari peneliti pendahulu yang relevan untuk penelitian ini. tidak banyak membahas terkait administrasi daftar pemilih yang dikaitkan dengan hak pilih warga negara dalam pemilu, Kartikasari (2018) dan Al Lutfi (2019) mengangkat tema penjaminan hak pilih bagi pasien yang berada di Rumah Sakit saat Pemilihan Kepala Daerah.

Tujuan penelitian tersebut agar terciptanya Pemilu yang inklusif dan temuan penelitian ini adalah terdapat pasien rumah sakit yang tidak dapatmemilih di RS disebabkan karena tidak mengetahui bagaimana prosedur pindah memilih. Selain itu, kurang maksimalnya pelayanan TPS Khusus di
RS diakibatkan surat suara yang disediakan juga sangat terbatas, sehingga tidak mencukupi untuk diberikan kepada seluruh pasien dan juga sulitnya akses untuk mengikuti pemilihan umum.

Persamaan penelitan ini dengan penelitian yang akan dilakukan penulis adalah bahwa pentingnya inklusifitas dalam pelaksanaan Pemilu terutama bagi pemilih khusus, dan yang menjadi pembedanya adalah segmen tema bahasan peneliti yang mengkaji tahanan dan narapidana dimana jumlah pemilih berada dalam posisi relatif tetap. Sedangkan pasien RS lebih cepat mengalami perubahan jumlah

Dengan latar belakang dan konsep teori di atas, serta signifikannya tahanan dan narapidana yang tidak dapat memilih pada Pemilu 2019 yang berada di Rumah Tahanan Kelas I Pekanbaru, maka penelitian ini bertujuan untuk mengetahui bagaiaman jaminan hak pilih bagi narapidana pada pemilu 2019 di Rutan Kelas I Pekanbaru, karena meskipun Indonesia tidak melakukan pencabutan hak pilih untuk narapidana, kenyataanya dalam penggunaan hak pilih di Rumah Tahanan masih mengalami hambatan, khususnya untuk pemilih yang memiliki KTP dari Kabupaten/Kota atau propinsi luar daerah penjara dan yang belum memiliki E-KTP.

\section{METODE}

Penelitian ini menggunakan pendekatan metode kualitatif deskriptif yaitu prosedur penelitian yang menekankan pada segi proses dari hasil penelitian yang mengungkapkan permasalahan sebagaimana adanya, yang kemudian menghasilkan data deskriptif berupa kata-kata tertulis atau lisan dari orang dan prilaku yang diamati.(Moleong, 2005: 4), Tujuan menggunakan pendekatan kualitatif deskriptif dalam rangka menggambarkan realita empiris terkait jaminan hak pilih bagi penghuni rumah tahanan, khususnya di Rumah 
Tahanan Kelas I Pekanbaru. Pengambilan data berupa data primer dan skunder. Dimana data primer diambil dengan metode wawancara dengan KPU Kota Pekanbaru, dan kepala Rutan kelas I Pekanbaru sedangkan data sekunder dengan studi dokumen baik berupa Undang-undang, peraturan KPU ataupun berita terkait permasalahan hak pilih narapidana.

\section{HASIL DAN PEMBAHASAN}

\section{Inklusivitas Pemilih di Lapas}

Rumah Tahanan (Rutan) adalah salah satu institusi yang dimiliki pemerintah yang berfungsi untuk membina warga binaan atau yang biasa disebut dengan Narapidana. Adapun definisi narapidana menurut UU No 12 tahun 1995 tentang permasyarakatan pada pasal 1 ayat 6 , adalah terpidana yang menjalani pidana hilang kemerdekaannya di lembaga permasyarakatan berdasarkan putusan pengadilan yang telah memperoleh kekuatan hukum tetap. Berdasarkan Peraturan Pemerintah no 32 tahun 1999 dijelaskan bahwa setiap warga binaan lembaga pemasyrakatan memilik hak politik yang tidak dapat dicabut hal ini diperjelas dalam pasal 51 bagian ketiga belas mengenai hak. Hak hak yang dimaksud di pasal ini adalah hak politik, hak memilih dan hak keperdataan lainnya. Dalam pasal 2 dijelaskan bahwa hak seorang narapidana sebagai anggota partai politik sesuai dengan aspirasinya dan di pasal 3 dijelaskan bahwa narapidana diberikan kesempatan untuk menggunakan hak pilinnya dalam pemilihan umum sesuai dengan undang undang yang berlaku.

Adapun karakteristik partisipasi politik Warga Binaan di dalam Lembaga Pemasarakatan tersebut cenderung terbatas, terutama untuk mengakses informasi mengenai Pemilu, keterbatasan ini tentunya akan menimbulkan efek terhadap tingkat partisipasi dari narapidana tersebut, dapat diketahui partisipasi akan berkaitan dengan informasi yang di dapat oleh narapidana. Partisipasi Warga binaan cenderung berbeda dengan pemilih pada umumnya karena Pemilih narapidana tidak bisa menjangkau informasi secara maksimal seperti pada pemilih yang ada diluar Lembaga Pemasyrakatan. Inklusivitas Lembaga Pemasyarakatan dalam proses pemilu diatur dalam UU Pemilu Nomor 7 Tahun 2017 yang menyebutkan bahwa Pemilih yang berhak untuk mengikuti pemungutan suara di TPS adalah pemilik KTP Elektonik yang terdaftar dalam Daftar Pemilih Tetap (DPT) di TPS yang bersangkutan, pemilik KTP-El yang terdaftar pada Daftar Pemilih Tetap Tambahan (DPTb), Pemilik KTP El yang tidak terdaftar pada DPT dan DPTb serta penduduk yang memiliki hak pilih ${ }^{6}$. Hal ini diperjelas lagi oleh KPU di dalam Peraturannya yang terkait dengan penyusunan Daftar Pemilih bahwa yang dimaksud dengan Daftar Pemilih Tetap Tambahan (DPTb) adalah data pemilih yang telah terdaftar dalam DPT di suatu TPS yang karena keadaan tertentu Pemilih tidak dapat menggunakan haknya untuk memilih di TPS tempat yang bersangkutan terdaftar dan memberikan suara di TPS lain. Keadaan tertentu yang dimaksud adalah sebagai berikut ${ }^{7}$ :

a. Menjalankan tugas pemerintahan di tempat lain pada hari PemungutanSuara

b. Menjalani rawat inap di rumah sakit atau puskesmas dan keluarga yang mendampingi

c. Penyandang disabilitas yang menjalani perawatan di panti sosial/panti rehabilitasi

\footnotetext{
${ }^{6}$ UU Nomor 7 Tahun 2017 tentang Pemilihan Umum Pasal 348

${ }^{7}$ Peraturan KPU Nomor 37 tahun 2018 tentang Perubahan atas PKPU Nomor 11 Tahun 2018 tentang Penyusunan Daftar Pemilih di Dalam Negeri dalam Pemilu Pasal 36
} 
d. Menjalani rehabilitasinarkoba;

e. Menjadi tahanan di rumah tahanan atau lembagapermasyarakatan;

f. Tugas belajar/menempuh pendidikan menengah atautinggi;

g. Pindah domisili;dan/atau

h. Tertimpa bencanaalam.

Pada poin huruf e keadaan tertentu di atas, Menjadi tahanan di rumah tahanan atau lembaga permasyarakatan mendapat perlakuan khusus dalam pemilu 2019 lalu. Terutama pada saat tahapan pindah memilih, penghuni Lapas dapat menggunakan hak pilihnya di TPS Lapas yang telah disiapkan oleh KPU. Pengadaan TPS dalam Lapas merupakan salah satu upaya KPU untuk menjamin tersalurkannya hak pilih warga negara yang sedang dalam masa penahanan, karena pada prinsipnnya hak memilih berlaku bagi seluruh warga Negara Indonesia.

Penyediaan TPS di Rutan Kelas I Pekanbaru dilksanakan oleh KPU Kota Pekanbaru juga atas dasar untuk menjamin hak pilih warga binaan, terlebih Pemilu Serentak 2019 merupakan kontestasi demokrasi yang sangat besar karena mencakup pemilihan Presiden dan Wakil Presiden, Pemilihan Anggota DPR RI, DPRD Provinsi, DPRD Kab/Kota dan Dewan Perwakilan Daerah (DPD). Tidaklah adil jika pemilih di Lapas tidak difasilitasi dalam perhelatan demokrasi sebesar itu.

Berdasarkan hasil wawancara Penulis dengan Mantan Ketua KPU Kota Pekanbaru Amirudin Sijaya, TPS di Lapas Kelas I Pekanbaru adalah sebagai bentuk perhatian pemerintah terhadap warga binaan yang hak politiknya sama dengan warga Negara biasa. la menjelaskan bahwa TPS di Lapas itu wajib diadakan sebagai jaminan hak politik warga binaan, karena memang mereka sama hak nya dengan kita yang di luar, undang-undang juga mengatur demikian yang juga diteruskan oleh PKPU dan turunannya ${ }^{8}$.

Pada saat penyusunan data pemilih, pemilih di lapas dilakukan pendataan secara khusus dengan berkoordinasi dengan pihak Lapas Kelas I Pekanbaru, untuk kemudian data tersebut ditindaklanjuti oleh KPU apakah warga binaan tersebut memenuhi syarat untuk mencoblos pada 17 April 2019.

Dibentuknya TPS di Lapas Kelas I Pekanbaru adalah sebagai refresentasi inklusivitas warga binaan dalam politik, yang kemudian diwujudkan pada kehadiran warga binaan tersebut di TPS pada saat pencoblosan. Sampai pada tataran ini, upaya untuk menjamin hak pilih warga binaan di Lapas kelas I Pekanbaru ditunjukkan dengan membentuk TPS di lapas tersebut.

\section{Proses Pendataan Pemilih di Rutan Kelas I Pekanbaru}

Untuk menjamin ketersediaan hak pilih warga binaan di Rutan kelas I Pekanbaru, KPU Kota Pekanbaru melakukan pendataan pemilih sesuai dengan tahapan yang telah ditetapkan oleh KPU RI. Adapun tahapan pendataan pemilih tersebut sebara garis besar terbagi atas tiga tahapan, yaitu

\section{Sosialisasi.}

melibatkan warga tahanan Rutan Kelas I Pekanbaru dalam proses politik untuk mengakomodir kepentingan mereka dan mengutamakan keterlibatan mereka dalam segala aspek kemasyarakatan.

Selama pemilu, ranah kewarganegaraan sering kali ditampilkan pada media dan non pemerintah lalu di definisikan menjadi kesadaran publik. Dalam hal ini adalah kesempatan untuk menembus stigma sosial dengan memastikan bahwa para warga binaan mempunyai hak yang sama dengan masyarakat sebagai peserta aktif dalam proses politik. Hanya saja peran dari warga binaan dalam proses politik lebih

\footnotetext{
${ }^{8}$ Wawancara tanggal 14 Mei 2020, Pukul 11.00 WIB
} 
terbatas, ada beberapa hal yang tidak bisa dilaksanakan oleh pemilih warga binaan diantaranya tidak dapat mengikuti kampanye terbuka secara langsung. Namun mereka tetap dapat melaksanakan proses pemantauan persiapan, pemilihan secara langsung, mengikuti proses setelah pemilihan yaitu perhitungan suara, penetapan calon terpilih hingga melaporkan kecurangan yang terjadi apabila ditemukan.

Maka untuk menjamin peran serta warga binaan seperti di atas terlaksana, maka tahapan sosialisasi mengenai tahapan, proses, syarat-syarat memilih, dan lain sebagainya merupakan langkah yang harus dilakukan. KPU Kota Pekanbaru memfasilitasi penyelenggaraan kegiatan memilih di Rutan Kelas I Kota Pekanbaru diawali dengan kegiatan sosialisasi.

Sosialisasi merupakan suatu kegiatan yang harus dilakukan kepada kelompok marjinal karena hak politiknya memiliki kedudukan yang sana dengan warga Negara yang lain, termasuk dalam hal ini warga binaan di Rutan Kelas I Pekanbaru.

Wawancara penulis dengan anggota KPU Kota Pekanbaru divisi Perencanaan dan Data Pemilih, Nurfajri menjelaskan bahwa salah satu fokus utama sosialisasi saat pemilu 2019 adalah warga binaan di Rutan kelas I Pekanbaru, dimana sosialisasi banyak dilakukan kepada kelompok-kelompok masyarakat, salah satu yang utama adalah sosialisasi di Rutan. Di Rutan ini diutamakan karena memang KPU menempatkan TPS di sana, kalau sosialisasi ke kelompok masyarakat lain kan mereka bisa memilih dimana saja. Memang Rutan ini sangat diutamakan ${ }^{9}$.

Sosialisasi pencoblosan di Rutan kelas I Pekanbaru dilaksanakan pada tanggal 23 Maret 2019 dengan menghadirkan Ketua KPU Kota

\footnotetext{
${ }^{9}$ Wawancara tanggal 16 mei 2020 Pukul 09.00 WIB
}

Pekanbaru, Ka Rutan Kelas I Pekanbaru, Anggota KPU Divisi Data, PPK dan PPS. Sosialiasi ini diutamakan untuk tata cara mencoblos agar pada hari pemilihan warga binaan tidak bingung.

\section{Penyusunan Data Pemilih}

Penyusunan data pemilih di Rutan kelas I Pekanbaru pada prinsipnya sama dengan proses penyusunan data pemilih secara umum, sebagaimana tergambar dalam alur di bawah ini:

Alur Penyusunan Data Pemilih Pada Pemilu 2019Di Kota Pekanbaru

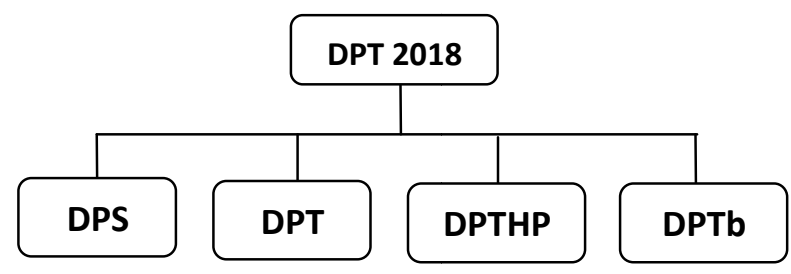

Sebagaimana halnya pendataan pemilih secara umum, di Rutan kelas I Pekanbaru proses pendataan pemilih dilakukan dengan mengikut alur di atas. DPT Pemilu 2019, dalam penyusunannya bersumber dari DPT sebelumnya yakni data pemilih Pemilihan Gubernur (PILGUBRI) 2018. Setelah DPT PILGUBRI 2018 tersebut diolah per TPS sesuai dengan yang sudah ditetapkan, maka DPT PILGUBRI 2018 di Rutan kelas I Pekanbaru secara otomatis menjadi DPS Pemilu 2019 di Rutan Kota Pekanbaru, DPS tersebut dilakukan pencermatan dan tanggapan masyarakat untuk kemudian ditetapkan sebagai DPT. Sesuai kebutuhan pemilih dan dinamikan yang terjadi, DPT Pemilu 2019 dilakukan perbaikan (DPTHP) sebanyak tiga kali. Setelah selesai perbaikan DPT tersebut barulah dilakukan penambahan pemilih yang belum terakomodir melalui DPTb, dalam DPTb ini juga sudah termasuk pindah memilih yang banyak dilakukan di dalam Rutan Kelas I Pekanbaru.

\section{Pindah Memilih di Lapas}

Hampir keseluruhan warga binaan

di Rutan kelas I Pekanbaru bukanlah 
penduduk setempat, melainkan dari berbagai daerah di Indonesia yang dilakukan penahanan di Rutan Kelas I Pekanbaru. Idelanya, para warga binaan tersebut sudah terdaftar sebagai pemilih di tempat tinggal asalnya, sehingga dalam proses pendataan pemilih di Rutan Kelas I Pekanbaru, sebagian besar masuk dalam kategori pemilih pindahan (DPTb).

Menurut Mickey Elsen petugas Rutan bagian Pengelolaan menjelaskan Sebagian besar warga binaan bukan warga tempatan (Pekanbaru), kalau kata KPU memilih harus KTP setempat, maka maka banyak warga binaan yang tidak dapat mmilih. Mungkin mekanisme selanjutnya akan ditetapkan oleh KPU dan kita siap membantu ${ }^{10}$.

Senada dengan pernyataan petugas Rutan di atas, Anggota KPU Kota Pekanbaru Divisi Perencanaan dan Data Nurfajri menjelaskan bahwa data pemilih di Lapas hanya sebagian kecil saja yang terdata sebagai DPT, selebihnya adalah pemilih pindahan karena asumsinya warga binaan tersebut sudah terdaftar di daerah asalnya, dan pemilih kebanyakan hanya boleh melakukan pencoblosan untuk Presiden dan untuk DPR RI". ${ }^{11}$

\section{Masalah Pendataan Pemilih di Rutan kelas I Pekanbaru}

\section{Persoalan Identitas Kependudukan} Ketentuan bahwa tahanan/ narapidana di lembaga pemasyarakatan masuk dalam kategori pemilih tambahan (DPTb) seperti yang sudah disebutkan di PKPU Nomor 11 tahun 2018 Pasal 36 ayat 3 point (e). Undang-Undang Pemilu yang mengharuskan bahwa pemilih wajib memiliki KTP Elektronik sebagai syarat untuk memilih, menjadi pekerjaan tambahan bagi KPU untuk mendata tahanan/narapidana yang memenuhi syarat yang berada di Lembaga

\footnotetext{
${ }^{10}$ Wawancara dengan Ka lapas kelas I Pekanbaru tanggal 19 Mei 2020 Pukul 14.00 WIB.

${ }^{11}$ Wawancara tanggal 14 Mei 2020 Pukul 11.00 WIB
}

pemasyarakatan. Tidak hanya mendata berdasarkan persyaratan umur dan status pemilih, tetapi kepemilikan KTP Elektronik yang menjadi syarat utama untuk memilih.

Permasalahan administrasi calon pemilih di Rutan Kelas I Pekanbaru yang belum bisa terverifikasi adalah data penghuni hanya nama dan alamat, sedangkan NIK dan KTP tidak diketahui, dan penghuni Rutan juga tidak membawa KTP elektronik atau Surat Keterangan menjadi hambatan saat pencoblosan ${ }^{12}$. Identitas dari penghuni Rutan yang sulit untuk ditelusuri ini menjadi hambatan bagi KPU untuk menyusun Daftar Pemilih Tetap (DPT) dan Daftar Pemilih Tambahan (DPTb).

Penelusuran identitas penghuni Rutan menjadi faktor penting dalam hal memfasilitasi pemilih di dalamnya. Kepemilikan KTP elektronik yang harus dimiliki penghuni Rutan menjadi kewenangan Dinas Kependudukan dan Catatan Sipil setempat untuk segera melakukan pendataan dan perekaman. Permasalahan penghuni Rutan yang sebagian penghuninya tidak memberikan identitas yang valid juga menjadi problem utama dalam pendataan dan perekaman. Jika calon pemilih tersebut telah melakukan perekaman data dalam KTP Elektronik, kemungkinan akan mudah dilakukan penelusuran, tetapi jika belum pernah dilakukan perekaman maka harus ada solusi yang harus dilakukan oleh dinas kependudukan untuk mengetahui identitas calon pemilih. Karena jika narapidana atau tahanan di Rutan banyak yang tidak memiliki kartu tanda penduduk atau KTP Elektronik maka akan menjadi penyumbang angka golput dalam Pemilu 2019.

\section{Keterbatasan Waktu Pendataan}

Waktu pendataan pemilih di Rutan Kelas I Pekanbaru cukup singkat karena menunggu validasi data yang dilakukan oleh pihak Rutan dan Disdukcapil Kota

\footnotetext{
${ }^{12}$ Wawancara dengan Nurfajri, ibid

Di akses pada tanggal 29 November 2019
} 
Pekanbaru. Data warga binaan yang dimiliki oleh pihak Rutan Kelas I Kota Pekanbaru sebagian besar hanya data nama, asal, dan jenis kelamin. Hal itu tidak memenuhi syarat untuk dimasukkan ke dalam daftar pemilih sehingga untuk memutakhirkan data tersebut dibutuhkan kerjasama dengan pihak Disdukcapil. Proses verifikasi dengan disdukcapil inilah yang memakan waktu cukup lama sementara tahapan terus berjalan.

\section{KESIMPULAN DAN SARAN}

Rendahnya warga binaan dan tahanan yang dapat memilih di Rutan Kelas I kota Pekanbaru pada Pemilu 2019 disebabkan oleh sulitnya menelusuri data otentik penghuni Rutan karena sebagian besar data warga binaan hanya berasal dari berkas pengadilan yang hanya berupa nama, jenis kelamin. Tidak memuat nomor induk kependududkan (NIK)

Karena tidak lengkapnya indentitas tahanan dan narapidana, maka jaminan hak pilih warga binaan di Rutan Kelas I Pekanbaru hanya dilaksanakan secara normatif oleh KPU Kota Pekanbaru sesuai tahapan dan prosedur yang berlaku, sehingga banyak narapidana yang berasal dari luar daerah tidak dapat diakomodir hak pilihnya.Sehingga disarankan perlunya koordinasi antar lembaga yang lebih kuat dan berkesinambungan antara KPU, Kementian Hukum dan Ham dan Kementrian dalam Negeri. Seanjutnya untuk memperkuat dan melengkapi regulasi yang dapat mempermudah proses pendataan tahanan dan narapidana ke dalam data pemilih baik untuk dapat terdaftar di DPT maupun prosedur pidah memilih yang lebih mundah

\section{DAFTAR PUSTAKA}

\section{Buku}

Moleong, Lexy J. 2005. Metode Penelitian Kualitatif. Bandung: PT Remaja Rosdakarya.

Ramadhani, Fadli Dkk. 2019 Evaluasi Pemilu Serentak 2019 : Dari Sistem Pemilu Ke Manajemen Pemilu. Jakarta : Perludem

Sanit, Arbi. 1992. GOLPUT : Aneka Pandangan Fenomena Politik. Jakarta : Pustaka Sinar Harapan.

Yard, Michea. 2011. Civil and Voter Registries: Lessons Learned from Global Experiences. Washington D.C. : International Foundation for Electoral Systems (IFES)

Jurnal, Artikel dan Hasil Penelitian

Al Mufti D. N. 2019. Re-Desain Penjaminan Hak Pilih Untuk Pasien Rumah Sakit Sebagai Upaya Mencapai Pemilu Yang Inklusif. Tata Kelola Pemilihan Jurnal Tata kelola pemilu Indonesia , 1 (1), 1. Diperoleh dari

//journal.kpu.go.id/index.php/TK P/article/view/32

Beckman, L. 2008.Democratic Inclusion, Law, and Causes. Ratio Juris. Volume 21 Issues 3. Halaman: 348-364. doi:10.1111/j.14679337.2008.00394.x

Birch, S. (2011). Electoral Malpractice. Oxford University Press.

Kartikasari, Wedarini. Menjamin Pemilu Inklusif : Studi tentang Pemungutan Suara Bagi Pasien Rawat Inap di Rumah Sakit. Universitas Airlangga Pekanbaru. 2017

Surbakti, R. 2016 . Pidato Inagurasi Anggota Baru Akademi IImu Pengetahuan Indonesia AIPI . Surabaya: Fakultas IImu Sosial 
dan IImu Politik Universitas

Airlangga

\section{Berita Online}

http://infopublik.id/read/262892/komnasham-minta-ada-tps-khusus-danregulasi-bagi-pemilih-Lapas.html

http://www.medanbisnisdaily.com/news/on line/read/2018/06/27/41953/532 _warga_binaan_Lapas_dan_rut an_tanjung_gusta_gunakan_hak suaral

https://tirto.id/hanya-1110-narapidanayang-tercatat-dalam-dpt-dilapas-cipinang-dmvK

https://www.liputan6.com/regional/read/39 43810/tidak-semua-napi-Lapasbisa-nyoblos-mengapa

\section{Sumber Undang-Undang dan Peraturan Undang-Undang Dasar Tahun 1945 \\ Undang-Undang Nomor 12 tahun 1995 Tentang Lembaga Pemasyarakatan : Tahanan / narapidana \\ Undang-Undang No. 12 Tahun 2005 Tentang Pengesahan Kovenan Internasional Hak-Hak Sipil dan Politik \\ Undang-Undang Nomor 7 Tahun 2017 Tentang Pemilihan Umum \\ Peraturan Pemerintah No. 32 Tahun 1999 tentang Syarat dan Tata Cara Pelaksanaan Hak Warga Binaan Pemasyarakatan \\ Peraturan Komisi Pemilihan Umum Nomor 37 tahun 2018 Tentang Perubahan atas PKPU Nomor 11 Tahun 2018 tentang Penyusunan}

